Удк 338.922.304

DOI: https://doi.org/10.32851/2708-0366/2021.10.6

Кириченко Н.В.

кандидат економічних наук, доцент, Херсонський державний аграрно-економічний університет ORCID: https://orcid.org/0000-0003-1721-258X

Жосан Г.В.

кандидат економічних наук, доцент,

Херсонський державний аграрно-економічний університет ORCID: https://orcid.org/0000-0002-3577-6701

Kyrychenko Natalia, Zhosan Hanna Kherson State Agrarian and Economic University

\title{
НАПРЯМИ УДОСКОНАЛЕННЯ СТРАТЕГІЇ КОНКУРЕНТОСПРОМОЖНОСТІ ТОРГОВОГО ПІДПРИЄМСТВА
}

\section{DIRECTIONS OF IMPROVING THE COMPETITIVENESS STRATEGY OF A TRADING ENTERPRISE}

В статті розкриваються основні напрями удосконалення стратегії конкурентоспроможності торгового підприємства. Визначено фактори, шуо впливають на конкурентоспроможність: комунікативна політика компаній-суперників; розробка нових товарів та присвоєння торгових брендів та марок; привабливість та якість пакування товарів; ефективність і організація сервісної політики фірм-конкурентів; організація збуту продукиї у суперників (конкурентів); раціональність каналів просування товарів у підприємств-аналогів. Встановлено, щзо поняття конкурентоспроможність практично складається з чотирьох груп факторів: техніко-економічні, комериійні, нормативно-правові, соиіальні. 3'ясовано, шьо на конкурентоспроможність впливають як зовнішні (державні, ринкові, сочіально-політичні), так і внутрішні (організаційна структура підприємства, фактор інновації продукції (робіт, послуг), якість продукції (робіт, послуг)) фактори.

Ключові слова: стратегія, конкурентоспроможність, підприємство, торгівля, менеджмент.

В статье раскрываются основные направления усовершенствования стратегии конкурентоспособности торгового предприятия. Определень факторы, влияющие на конкурентоспособность: коммуникативная политика соперников; разработка новых товаров и присвоение торговых брендов и марок; привлекательность и качество упаковки товаров; эффективность и организация сервисной политики фирм-конкурентов; организация сбыта продукции у конкурентов (конкурентов); рациональность каналов продвижения товаров у предприятий-аналогов Установлено, что понятие конкурентоспособности практически состоит из четырех групп факторов: технико-экономические, коммерческие, нормативно-правовые, социальные. Установлено, что на конкурентоспособность влияют как внешние (государственные, рыночные, социильно-политические), так и внутренние (организационная структура предприятия, фактор инновации продукции (работ, услуг), качество продукции (работ, услуг)) факторы.

Ключевые слова: стратегия, конкурентоспособность, предприятие, торговля, менеджмент.

The article reveals the main directions of improving the competitiveness strategy of a commercial enterprise. Factors influencing competitiveness are identified: communication policy of rival companies; development of new products and assignment of trade marks and brands; attractiveness and quality of packaging of goods; efficiency and organization of service policy of competing firms; organization of sales of products from rivals (competitors); rationality of channels of promotion of goods at the enterprises-analogues. It is established that the concept of competitiveness practically consists of four groups of factors: technical and economic, commercial, regulatory, social. It was found that competitiveness is influenced by both external (government, market, socio-political) 
and internal (organizational structure of the enterprise, the factor of product innovation (works, services), product quality (works, services)) factors. It is established that the success or lag of a trading company is assessed by comparing its condition in relation to competing companies. This state is determined by a certain set of product properties and the provision of trade services by the enterprise, due to which a certain competitive advantage is created. In this case, if there are no competitors in the market that provide services for the sale of similar goods, the question of the competitiveness of the trading company is removed automatically. For the purposes of managing the competitiveness of a trading company, it is necessary to combine the chosen competitiveness strategy with the tools of competitiveness management, which should include:

- conducting marketing research;

- constant monitoring of selected indicators as criteria of competitiveness (assessment of the dynamics of own enterprise for a number of similar periods; comparison of indicators on selected criteria with the reference company, etc.);

- measuring and forecasting the demand for goods sold by the trading company (groups of goods);

- pricing management, etc.

In further research, from general theoretical issues, we turn to the activities of real trading companies, analysis of their methods and techniques of competition.

Key words: strategy, competitiveness, enterprise, trade, management.

Постановка проблеми. У ринковій економіці конкуренція $є$ однією з головних рис, оскільки саме вона створює особливі умови для господарювання ринкових суб'єктів, забезпечуючи цим умови для створення та реалізації нових товарів та послуг.

Показником важливості конкуренції для сучасного ринку є той факт, що на сьогоднішній день в більшості країн розроблені та прийняті закони, що дозволяють захищати та підтримувати конкуренцію. При цьому основою конкурентної економіки - конкурентоспроможні компанії та підприємства всіх форм власності та сфер діяльності.

В сучасних умовах нестабільного турбулентного зовнішнього середовища однією 3 основних цілей діяльності будь-якого підприємства $є$ перемога у конкурентній боротьбі, або створення об'єднань (кластерів) для підсилення своїх позицій та виділення на фоні компаній-аналогів. А для того, щоб перемоги та завойовувати прихильність споживачів, конкурентоспроможністю необхідно керувати, постійно розробляти заходи, спрямовані на іiі підвищення. Такі тенденції визначають актуальність теми, обраної для дослідження, робить цікавою їі для вивчення.

Аналіз останніх досліджень і публікацій. На даний час питання підвищення рівня конкурентоспроможності підприємств, в тому числі торгових перебуває в центрі уваги як вітчизняних, так і закордонних учених, а саме: О. В. Ареф'євої, С. Т. Пілецької [1], Л. В. Балабанової [2], 3. В. Юринець [3], М. Портера [4], 3. М. Побережної [5], I. М. Мягких [6], М. С. Рогози [7], І. А. Павленко [8], В. П. Соловйова [9] та ін. Проте питання формування напрямів удосконалення стратегії конкурентоспроможності торгових підприємства $є$ недостатньо розкритим та потребує поглиблення, чим обумовлено актуальність дослідження.

Формулювання цілей статті. Визначити основні напрями удосконалення стратегії конкурентоспроможності торгового підприємства.

Виклад основного матеріалу. В період пандемії та постпандемії для досягнення певного успіху в сучасній ринковій економіці вирішальним елементом має стати ефективне використання різних факторів, що впливають на конкурентоспроможність:

1. Комунікативна політика компаній-суперників.

2. Розробка нових товарів та присвоєння торгових брендів та марок.

3. Привабливість та якість пакування товарів.

4. Ефективність і організація сервісної політики фірм-конкурентів.

5. Організація збуту продукції у суперників (конкурентів).

6. Раціональність каналів просування товарів у підприємств-аналогів.

Іншими словами, фактори конкурентоспроможності відображають показники, що беруть участь у специфічній боротьбі підприємницьких структур за попит власної продукції, розширення кола споживачів та зростання частки на сучасному ринку. 


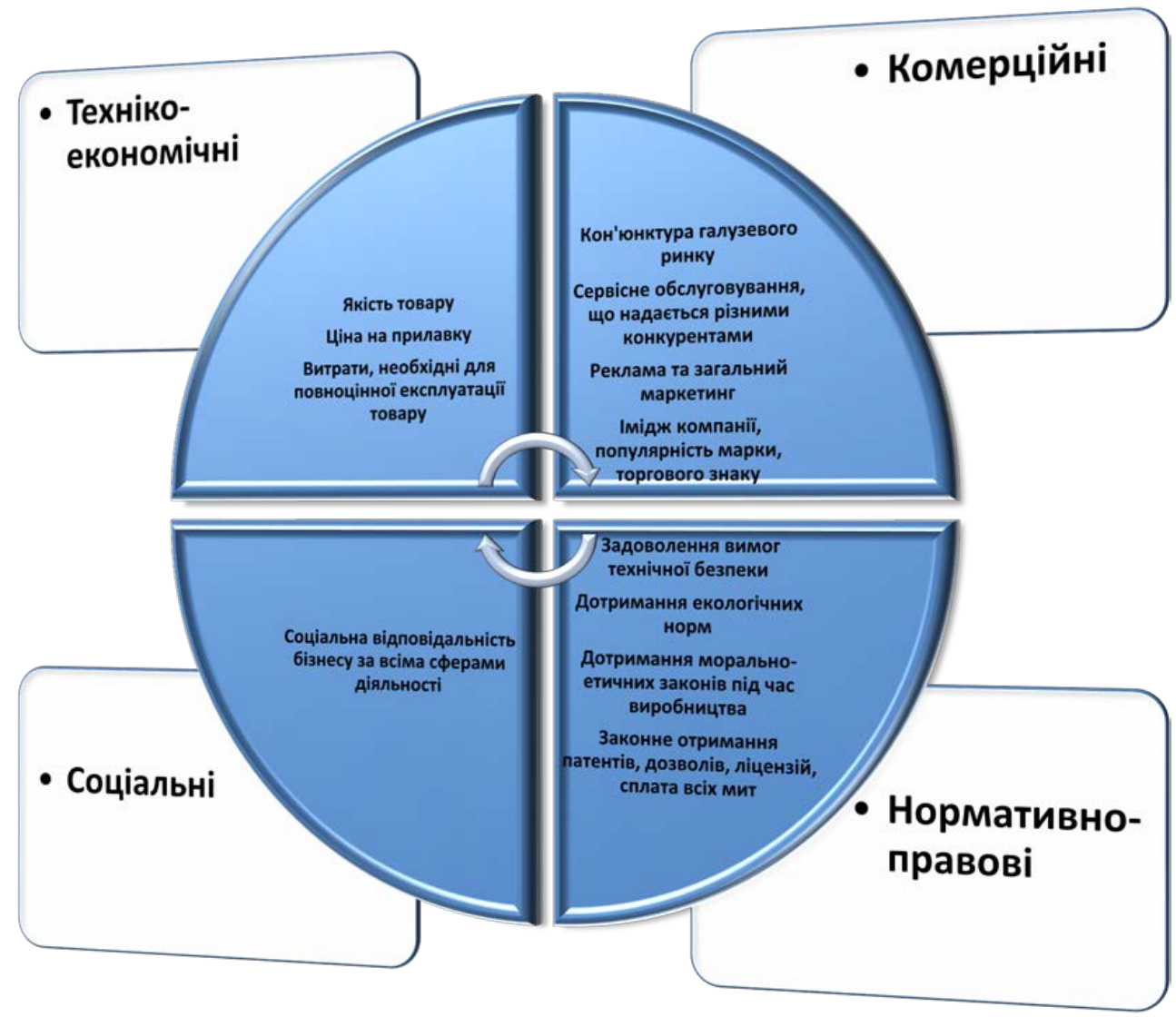

Рис. 1. Групи факторів конкурентоспроможності підприємств

В цілому ж, поняття конкурентоспроможність практично складається $з$ чотирьох груп факторів (рис. 1).

Кон'юнктура галузевого ринку - це рівень активної конкуренції, співвідношення попиту та пропозиції, особливості території національні, релігійні, культурні, і навіть платоспроможність населення, та інші.

Сервісне обслуговування, що надається різними конкурентами - чи є дилерські та сервісні мережі, якість ремонтів, гарантійне обслуговування, тощо.

Реклама та загальний маркетинг - чи ведеться робота у цьому напрямку.

Імідж компанії, популярність марки, торгового знаку, загальна лояльність споживачів до компанії та іiі продуктів.

Крім того, на конкурентоспроможність впливають як зовнішні (державні, ринкові, соціально-політичні), так і внутрішні (організаційна структура підприємства, фактор інновації продукції (робіт, послуг), якість продукції (робіт, послуг)) фактори.

До зовнішніх факторів, що впливають на ефективність господарської діяльності різних підприємницьких структур, які можуть використовувати аналіз конкурентоспроможності, можна віднести:

- державні фактори, виражені в економічних методах (наприклад, амортизаційна та податкова політика, фінансово-кредитна та інвестиційна політика, цільові програми та митна політика) та адміністративно-правових методах (сертифікації, стандартизаціі); 
- ринкові фактори, визначені типом та ємністю ринку, конкурентами, трудовими ресурсами, ринком праці, рівнем доходу та галузевими особливостями;

- соціально-політичні чинники як громадських організацій, політичної стабільності, рівня культури та соціального становища.

До внутрішніх факторів конкурентоспроможності відносять:

- організаційну структуру підприємства (наприклад, фінансово-економічний та виробничо-технологічний потенціал, а також матеріально-технічне забезпечення);

- інноваційний фактор, виражений у кадровому потенціалі, контролі та аналізі інновацій, системі сертифікатів та стандартів;

- якість обслуговування та експлуатації у формі упаковки, зберігання, транспортування продукції, екологічності продукції, можливості утилізації тощо.

Конкурентоспроможність пов'язана з: по-перше, визначенням ступеня відповідності всієї виробничо-технічної структури вимогам у сфері маркетингу, оцінки можливості ефективного ресурсозбереження під час випуску якісної та економічної продукції. По-друге, підвищення рівня суперництва підприємств може впливати на рівень усвідомлення співробітниками стратегії організації та іiї цілей. По-третє, підвищення конкурентоспроможності нормативної бази залежить від регламентних актів, технологічної та методичної документації, а також різних якостей готової продукції. По-четверте, суперництво у сфері інформаційних ресурсів може виражатися у певній практичній застосовності та системності.

Конкурентоспроможність торгових підприємств це можливість перемоги в економічній боротьбі з аналогічними підприємствами за споживача та додаткові доходи (у вигляді зростання виручки від реалізаціі).

Обов'язковим атрибутом конкурентоспроможного торгового підприємства $є$ успішність його комерційної діяльності та фінансова стійкість.

Розглянемо умови забезпечення конкурентоспроможності підприємства торгівлі.

Конкурентоспроможність підприємств торгівлі можна оцінювати за такими напрямами (рис. 2).

Успіх чи відставання торгового підприємства оцінюють, порівнюючи його стан стосовно підприємств-конкурентів. Такий стан визначається певним набором властивостей товару та наданням підприємством торгівлі послуг, завдяки яким і створюється певна конкурентна перевага. При цьому якщо ринку немає конкурентів, які надають послуги з реалізації аналогічного товару, питання про конкурентоспроможність даного торгового підприємства знімається автоматично.

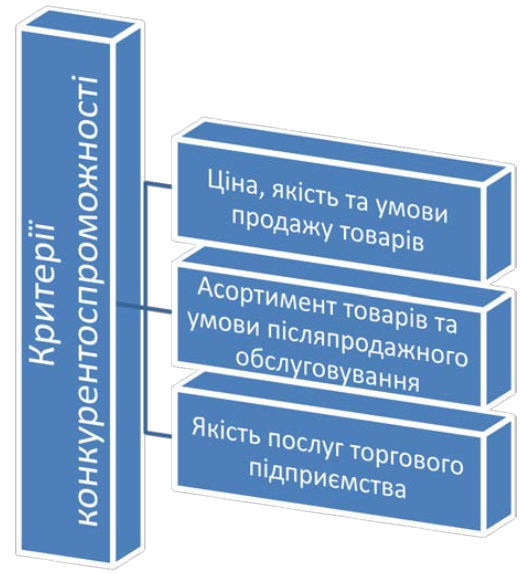

Рис. 2. Критерії конкурентоспроможності підприємства торгівлі 
За наявності ж ринку інших торгових підприємств, що реалізують аналогічні (ні) товари, виникає конкуренція, і вступають у дію чинники, зазначені рисунку 2.

Ціна, якість та умови продажів - найважливіші фактори конкурентоспроможності торгового підприємства. Якісний товар, який реалізований (напротивагу іншим торговим підприємствам) за нижчими цінами, за умов довгострокового чи безпроцентного кредиту, приверне більше споживачів, ніж у аналогічні торгові підприємства. Також на рівень конкурентоспроможності торговельного підприємства значний вплив мають асортимент товарів, умови їх гарантійного та післяпродажного обслуговування, а також якість послуг, що надаються самим торговим підприємством.

Відомо, що підприємство торгівлі не виробляє реалізований товар (навіть якщо це фірмовий магазин від підприємства-виробника). Воно лише надає послуги споживачам продукції з реалізації товарів. І від якості послуг торговельного підприємства, а саме:

- зручне для споживачів розташування, наявність паркувань;

- доступність товарів для ознайомлення;

- ввічливість та компетентність торгового персоналу тощо.

багато в чому залежить величина попиту на товар (при рівних цінових характеристиках у конкуруючих торгових підприємств).

Висновки. У сфері торгівлі конкурентоспроможність - це здатність підприємства виділити свої переваги та зробити їх унікальними. Чим більш потрібні споживачам ці переваги, тим більший рівень конкурентоспроможності. Споживач постійно порівнює товари аналогічних лінійок, робить висновки, і лише тоді купує. У цей процес включаються ще кілька факторів: лояльність і ступінь довіри до марки, довіра або недовіра до конкурентних товарів, можливість отримання разом з купівлею додаткових вигод та бонусів.

Якщо товари підприємства конкурентоспроможні, тоді й саме торгове підприємство здатне витримати конкурентну боротьбу на ринку.

Для цілей управління конкурентоспроможністю торгового підприємства необхідно поєднувати обрану стратегію конкурентоспроможності з інструментами управління конкурентоспроможністю, до яких слід віднести:

- проведення маркетингових досліджень;

- постійний моніторинг обраних показників як критеріїв конкурентоспроможності (оцінка динаміки по власному підприємству за ряд аналогічних періодів; порівняння показників за обраними критеріями з підприємством-еталоном тощо);

- вимірювання та прогнозування попиту на реалізовані торговим підприємством товари (групи товарів);

- управління ціноутворенням тощо.

В подальших дослідженнях, від загальних теоретичних питань, перейдемо до розгляду діяльності реальних торговельних підприємств, аналізу застосовуваних ними методів та прийомів конкурентної боротьби.

\section{Список використаних джерел:}

1. Ареф'єва О. В., Пілецька С. Т. Просторово-адаптивний підхід до формування конкурентної стратегії підприємства. Бізнес Інформ. 2018. № 5. С. 408-415. URL: https://www.business-inform.net/ export_pdf/ business-inform-2018-5_0-pages-408_415.pdf

2. Балабанова Л. В., Кривенко А. В. Управление конкурентоспособностью предприятий на основе маркетинга. Донецк, 2008. 147 с.

3. Юринець 3. В. Формування інноваційних стратегій : монографія. Львів : СПОЛОМ, 2016. $412 \mathrm{c}$.

4. Портер М. Э. Конкуренция / пер. с англ. Москва : ИД «Вильямс», 2005. 608 с.

5. Побережна 3. М. Методичне забезпечення оцінювання ефективності заходів з підвищення конкурентоспроможності авіакомпаній. Економіка та держава. 2017. № 1. С. 29-31. URL: http://www.econ.-omy.in.ua/?op=1\&z=3677\&i=5 
6. Мягких I. М. Теоретико-методичний підхід до комплексної оцінки інвестиційної діяльності авіаційного підприємства. Економічний вісник Дніпровської політехніки. 2016. № 1. C. 110-116. URL: https://ev.nmu.org.ua/docs/2016/1/EV20161_110-116.pdf

7. Рогоза М. Є., Вергал К. Ю. Теоретичні аспекти формування моделі стратегічного інноваційного розвитку підприємства. Економічний вісник Національного гірничого університету. 2008. № 3. C. 91-96. URL: https://core.ac.uk/download/pdf/48399182.pdf

8. Павленко I. А. Інноваційне підприємництво у трансформаційній економіці України : монографія. Київ : КНЕУ, 2007. 248 с.

9. Соловйов В. П. Інноваційна діяльність як системний процес у конкурентній економіці : дис. ... д-ра екон. наук : 08.02.02. Київ, 2006. 558 с.

10. Yurii Kyrylov, Natalia Kyrychenko, Tatyana Stukan and Hanna Zhosan. Formation of Enterprise Management Strategies and Entrepreneurship Training. International Journal of Management. 2020. 11(6). P. 793-800. Available at: http://www.iaeme.com/MasterAdmin/Journal_uploads/ijm/ VOLUME 11 ISSUE 6/IJM 1106 067.pdf

11. Kyrylov Y., Hranovska V., Z Zhosan H. Formation of the national competitive model of agricultural enterprises development under the conditions of globalization. Bulletin of the National Academy of Sciences of the Republic of Kazakhstan. 2021. Volume 2. Number 390. P. 81-89. DOI: https://doi.org/10.32014/2021.2518-1467.54

\section{References:}

1. Arefieva, O. V., and Piletska, S. T. (2018) "Prostorovo-adaptyvnyi pidkhid do formuvannia konkurentnoi stratehii pidpryiemstva" [The Spatial-Adaptive Approach to Formation of Competitive Strategy of Enterprise]. Biznes Inform, no. 5, 408-415. Available at: https://www.business-inform.net/ export_pdf/business-inform-2018-5_0-pages-408_415.pdf

2. Balabanova, L. V., and Krivenko, A. V. (2008) Upravleniye konkuren- tosposobnostyu predpriyatiy na osnove marketinga [Marketing-based Enterprise Competitiveness Management]. Donetsk.

3. Yurynets, Z. V. (2016) Formuvannia innovatsiinykh stratehii [Formation of Innovation Strategies]. Lviv: SPOLOM.

4. Porter, M. E. (2005) Konkurentsiya [Competition]. Moscow: ID «Vilyams».

5. Pobrezhna, Z. M. (2017) "Metodychne zabezpechennia otsiniuvannia efektyvnosti zakhodiv z pidvyshchennia konkurentospromozhnosti aviakompanii" [Methodical Providing Evaluation of the Effectiveness of Measures to Improve the Competitiveness of Airlines]. Ekonomika ta derzhava, no. 1, 29-31. Available at: http://www.economy.in.ua/?op=1\&z=3677\&i=5

6. Miahkykh, I. M. (2016) "Teoretyko-metodychnyi pidkhid do kompleksnoi otsinky investytsiinoi diialnosti aviatsiinoho pidpryiemstva" [Theoretical and Methodological Approach to the Integrated Assessment of Aviation Enterprise Investment Activities]. Ekonomichnyi visnyk Dniprovskoi politekhniky, no. 1, 110-116. Available at: https://ev.nmu.org.ua/docs/2016/1/EV20161_110-116.pdf

7. Rohoza, M. Ye., and Verhal, K. Yu. (2008) "Teoretychni aspekty formuvannia modeli stratehichnoho innovatsiinoho rozvytku pidpryiemstva" [Theoretical Aspects of Forming a Model of Strategic Innovative Development of the Enterprise]. Ekonomichnyi visnyk Natsionalnoho hirnychoho universytetu, no. 3, 91-96. Available at: https://core.ac.uk/download/pdf/48399182.pdf

8. Pavlenko, I. A. (2007) Innovatsiine pidpryiemnytstvo u transformatsiinii ekonomitsi Ukrainy [Innovative Entrepreneurship in the Transformational Economy of Ukraine]. Kyiv: KNEU.

9. Soloviov, V. P. (2006) "Innovatsiina diialnist yak systemnyi protses u konkurentnii ekonomitsi“ [Innovation as a Systemic Process in a Competitive Economy]: dys. ... d-ra ekon. nauk: 08.02.02.

10. Yurii Kyrylov, Natalia Kyrychenko, Tatyana Stukan and Hanna Zhosan (2020) Formation of Enterprise Management Strategies and Entrepreneurship Training, International Journal of Management, 11(6), 793-800. Available at: http://www.iaeme.com/MasterAdmin/Journal_uploads/ijm/ VOLUME_11_ISSUE_6/IJM_11_06_067.pdf

11. Kyrylov Y., Hranovska V., Zhosan H. (2021) Formation of the national competitive model of agricultural enterprises development under the conditions of globalization. Bulletin of the National Academy of Sciences of the Republic of Kazakhstan, vol. 2, no. 390, pp. 81-89. DOI: https://doi.org/10.32014/2021.2518-1467.54 